Research review paper

\title{
Fermentation of lactose to bio-ethanol by yeasts as part of integrated solutions for the valorisation of cheese whey
}

\author{
Pedro M.R. Guimarães, José A. Teixeira, Lucília Domingues* \\ IBB-Institute for Biotechnology and Bioengineering, Centre of Biological Engineering, Universidade do Minho, Campus de Gualtar, 4710-057 Braga, Portugal
}

\section{A R T I C L E I N F O}

\section{Article history:}

Received 15 June 2009

Received in revised form 3 February 2010

Accepted 4 February 2010

Available online 11 February 2010

\section{Keywords:}

Lactose fermentation

Cheese whey

Bio-ethanol

Yeast

Kluyveromyces

Recombinant S. cerevisiae

\begin{abstract}
A B S T R A C T
Cheese whey, the main dairy by-product, is increasingly recognized as a source of many bioactive valuable compounds. Nevertheless, the most abundant component in whey is lactose (ca. $5 \% \mathrm{w} / \mathrm{v})$, which represents a significant environmental problem. Due to the large lactose surplus generated, its conversion to bio-ethanol has long been considered as a possible solution for whey bioremediation. In this review, fermentation of lactose to ethanol is discussed, focusing on wild lactose-fermenting yeasts, particularly Kluyveromyces marxianus, and recombinant Saccharomyces cerevisiae strains. The early efforts in the screening and characterization of the fermentation properties of wild lactose-consuming yeasts are reviewed. Furthermore, emphasis is given on the latter advances in engineering $S$. cerevisiae strains for efficient whey-to-ethanol bioprocesses. Examples of industrial implementation are briefly discussed, illustrating the viability of whey-to-ethanol systems. Current developments on strain engineering together with the growing market for biofuels will likely boost the industrial interest in such processes.
\end{abstract}

(c) 2010 Elsevier Inc. All rights reserved.

\section{Contents}

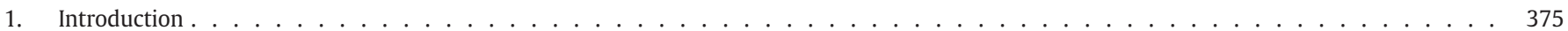

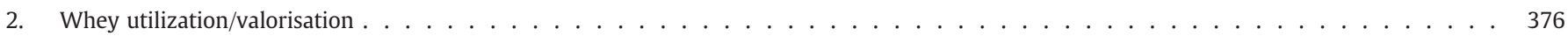

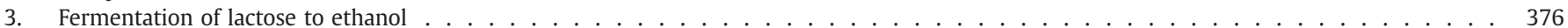

3.1. Kluyveromyces spp. . . . . . . . . . . . . . . . . . . . . . . . . . . . . . . . . . . . 377

3.2. C. pseudotropicalis $($ C. kefyr $) \ldots \ldots \ldots$

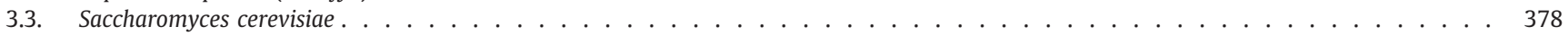

3.4. Industrial production of ethanol from whey . . . . . . . . . . . . . . . . . . . . . . . . . . 382

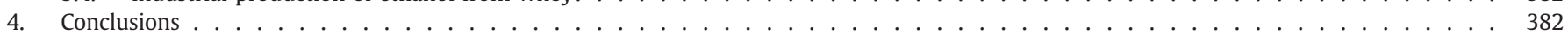

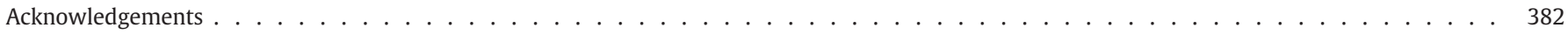

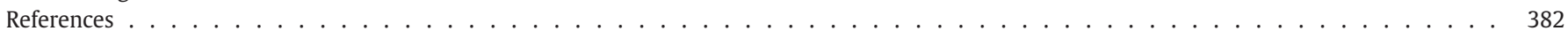

\section{Introduction}

Cheese whey is a by-product of dairy industries, particularly the watery portion that is formed during the coagulation of milk casein in cheese making or in casein manufacture. Whey is produced in large amounts and has a high polluting load, therefore representing a significant environmental problem. On the other hand, however, whey retains much of the milk nutrients, including functional proteins and peptides, lipids, lactose, minerals and vitamins and therefore has a vast potential as a source of added value compounds, challenging

\footnotetext{
* Corresponding author. Tel.: + 351253604 400; fax: + 351253678986 E-mail address: luciliad@deb.uminho.pt (L. Domingues).
}

the industry to face whey surplus as a resource and not only as a waste problem.

The utilization of whey has been a challenge since man started making cheese. As cheese production increased, the volume of whey also grew and many cheese factories were built near waterways so that most of the whey was diverted to these streams or rivers (Kosikowski, 1979). Modern times brought the awareness of the polluting problem that whey represents and the consequent regulations prohibiting its dumping into waterways and even into municipal sewage systems, whose conventional treatments are not appropriate to sufficiently reduce whey polluting load (Kosikowski, 1979).

Whey represents about $85-95 \%$ of the milk volume and retains 55\% of milk nutrients. Among the most abundant of these nutrients are 
lactose $(4.5-5 \% \mathrm{w} / \mathrm{v})$, soluble proteins $(0.6-0.8 \% \mathrm{w} / \mathrm{v})$, lipids $(0.4-0.5 \%$ $\mathrm{w} / \mathrm{v}$ ) and mineral salts (8-10\% of dried extract). Whey also contains appreciable quantities of other components, such as lactic $(0.05 \% \mathrm{w} / \mathrm{v})$ and citric acids, non-protein nitrogen compounds (urea and uric acid) and B group vitamins (Siso, 1996). There are two main varieties of whey, according to the procedure used for casein precipitation: acid whey $(\mathrm{pH}<5)$, resulting from the production of fresh or soft cheeses (such as cream and cottage cheese), and sweet whey ( $\mathrm{pH} \mathrm{6-7),}$ resulting from hard (ripened) cheeses (Kosikowski, 1979; Siso, 1996; Yang and Silva, 1995; Zall, 1984). The composition of different types of whey is variable; approximate figures for the main components can be found in the literature (see e.g. Kosikowski, 1979; Pesta et al., 2007; Yang and Silva, 1995).

Cheese whey represents an important environmental problem because of the high volumes produced and its high organic matter content. As a general rule of thumb, to make $1 \mathrm{~kg}$ of cheese about $9 \mathrm{~L}$ of whey are generated (Kosikowski, 1979). The world whey production is over 160 million tonnes per year (estimated as 9-fold the cheese production), showing a 1-2\% annual growth rate (OECD-FAO, 2008; Smithers, 2008). Whey exhibits a biochemical oxygen demand (BOD) of $30-50 \mathrm{~g} \mathrm{~L}^{-1}$ and a chemical oxygen demand (COD) of $60-80 \mathrm{~g} \mathrm{~L}^{-1}$. Lactose is largely responsible for the high BOD and COD. Protein recovery reduces the COD of whey only by about $10 \mathrm{~g} \mathrm{~L}^{-1}$ (Domingues et al., 1999a; Siso, 1996).

\section{Whey utilization/valorisation}

Earliest ways of whey disposal included piping into rivers, lakes or the ocean, funnelling into caves, spreading over fields and feeding into ruminants. Another option would be to discharge the whey into lagoons for oxidation or into the municipal sewage system, but the high BOD and COD of whey usually leads to an overload of the system (Kosikowski, 1979; Smithers, 2008). Disposing of whey by these means provides no valuable product, and is costly and labour demanding for the cheese manufacturer, who generally bears all the direct costs of handling and transport. Therefore, in spite of the fact that removal of whey from the premises releases pressure on the cheese manufacturing plant (Kosikowski, 1979), these solutions are not satisfactory. In order to develop integrated solutions for the cheese whey problem, it must be considered as a resource and not only as a waste effluent, in view of its large potential as a source of added value products.

Siso (1996) reported that about 50\% of total world cheese whey production is treated and transformed into various food products. This percentage will likely increase, due to continued research efforts in the field of whey utilization together with the pressure exerted over cheese and casein producers by aggravated legislations concerning effluent disposal.

A large fraction of the whey that is processed is dried to produce cheese whey powders (Kosikowski, 1979; Yang and Silva, 1995), therefore maintaining the quality of fresh whey for a longer period of time, facilitating manipulation and transport (Siso, 1996). Whey powder is mostly used for animal feeding but smaller quantities may be also used in human foods, such as ice-creams, baked goods, cakes, sauces, milk derivatives, etc (Siso, 1996).

The first step in most procedures for cheese whey valorisation consists in the recovery of the protein fraction. Whey proteins represent about $20 \%$ of the milk proteins, having a high nutritional value as well as reported health benefits and therapeutic potential (Beaulieu et al., 2006; Smithers, 2008; Yalçin, 2006). Separation of whey proteins is typically achieved by ultrafiltration or diafiltration to produce whey protein concentrates (WPC), which have many applications in the food industry (Kosikowski, 1979; Siso, 1996; Smithers, 2008; Zall, 1984). Whey proteins have also non-food uses, mainly in cosmetics and pharmaceutical products (Audic et al., 2003).
During the processing of whey for the production of WPC, high volumes of a lactose-rich stream, the permeate, are also obtained. The permeate remains a major pollutant since it retains the lactose, which represents more than $70 \%$ of total whey solids and is largely responsible for the whey polluting load. Therefore, the permeate creates disposal problems, in terms of volumes produced and polluting load, almost equal to the disposal of raw whey (Zall, 1984).

Lactose is the sugar present in the milk of most mammals. It is a disaccharide formed by galactose and glucose and is chemically defined as O- $\beta$-D-galactopyranosyl-(1-4)- $\beta$-D-glucose, $\mathrm{C}_{12} \mathrm{H}_{22} \mathrm{O}_{11}$ (Adam et al., 2004; Gänzle et al., 2008; Yang and Silva, 1995). The solubility and sweetness of lactose is low compared to other sugars, namely its hydrolysis products glucose and galactose, as well as fructose and sucrose (Gänzle et al., 2008; Zadow, 1984). Most of the lactose produced is recovered from whey or whey permeate by a process involving crystallisation (for details see Yang and Silva, 1995; Gänzle et al., 2008). The major uses for lactose include food ingredient, ingredient in infant formula, filler or coating agent for tablets in the pharmaceutical industry and raw material for the production of added value lactose derivatives (such as lactulose, lactitol, lactobionic acid, lactosyl urea, galacto-oligosaccharides and lactosucrose) (Audic et al., 2003; Gänzle et al., 2008; Yang and Silva, 1995; Zadow, 1984). Hydrolysed lactose solutions possess greater sweetening power than lactose and have foodrelated uses, particularly in the confectionery and ice-cream industries replacing sucrose or starch syrup (Siso, 1996; Zadow, 1984). The technology to produce hydrolysed lactose syrup is well developed and is used, for instance, to produce lactose-hydrolysed dairy products for lactose-intolerant individuals (Gänzle et al., 2008). Chemical hydrolysis at low pH $(<1.5)$ and high temperature (up to $150{ }^{\circ} \mathrm{C}$ ) is possible, but enzymatic hydrolysis is usually the method of choice, with enzymes from Aspergillus and Kluyveromyces species being the most commonly used (Gänzle et al., 2008; Yang and Silva, 1995; Zadow, 1984).

Another major application for the lactose in whey or permeate involves its use as a substrate for the production of valuable compounds by fermentation. The classical examples are ethanol (see below) and single cell protein (SCP) production in yeast-based bioprocesses, although biotechnologists have proposed a multitude of alternative bioproducts (Audic et al., 2003; Pesta et al., 2007; Siso, 1996; Yang and Silva, 1995; Zadow, 1984). Among those bio-products are: biogas (methane), organic acids (acetic, propionic, lactic, citric, gluconic, itaconic, and gibberelic), amino acids (glutamic, lysine, and threonine), vitamins (B12 and B2, or cobalamins and riboflavin, respectively), polysaccharides (xanthan gum, dextran, phosphomannan, pullulan, and gellan), oils (lipids), enzymes ( $\beta$-galactosidase and polygalactorunase) and other compounds (fructose-diphosphate, 2,3-butanediol, calcium magnesium acetate, ammonium lactate, butanol, and glycerol). Lactose can be used directly by lactose-consuming microorganisms or, alternatively, pre-hydrolysed lactose solutions may be used as substrate by lactosenegative microorganisms. Large whey surplus together with the need for cheap and largely available substrates and, above all, the rapid advances in microbial biotechnology are likely to prompt further exploitation of whey lactose as fermentation feedstock to obtain valueadded products.

\section{Fermentation of lactose to ethanol}

Alcoholic fermentation is an interesting alternative for the bioremediation of the polluting permeate that remains after separation of the whey proteins. The fermentation of whey lactose to ethanol, particularly using yeasts, has been frequently referred in the literature, since at least the 1940s (see e.g. Rogosa et al., 1947; Webb and Whittier, 1948; Whittier, 1944 and references therein). Although the yeasts that assimilate lactose aerobically are widespread, those that ferment lactose are rather rare (Fukuhara, 2006), including e.g. Kluyveromyces lactis, K. marxianus, and Candida pseudotropicalis. 
The conversion of the lactose in cheese whey or whey permeate into fuel ethanol is hardly economically competitive with the currently established processes, using cane sugar and cornstarch as substrates, or with emerging second generation technologies using lignocellulosic biomass as raw material. However, being a waste product represents an advantage of whey over food-related fermentation feedstocks, such as corn, for ethanol production. Moreover, the availability of diverse solutions for whey bioremediation is valuable, so that each dairy company can evaluate, according to its own specificities, the best way to deal with the environmental problem created by whey surplus. Finally, whey ethanol is potable, and therefore can find proper markets, e.g. in food and beverages, pharmaceutical and cosmetic industries.

It is noteworthy that the amounts of lactose available are rather significant. As a simple exercise, if we take into account an annual world production of 160 million tonnes of whey (OECD-FAO, 2008) with $5 \%$ lactose this means 8 million tonnes of lactose. Some authors have estimated that, over the past 50 years, half of the worldwide whey production has not been transformed into sub-products but disposed of as waste effluent (Becerra et al., 2001a; Siso, 1996); for instance, lactose surplus (i.e. the lactose not used for whey products) in the United States during 2006 was estimated to be above 55\% of total lactose in the whey produced (Ling, 2008). Therefore, the amount of lactose available for ethanol production may be as high as 4 million tonnes per year, which, considering a conversion efficiency of $85 \%$, could yield about 2.3 million $\mathrm{m}^{3}$ of ethanol. This is roughly $3.5 \%$ of the total world production of ethanol in 2008, which was around 65 million $\mathrm{m}^{3}$ (RFA, 2009).

Direct fermentation of whey or whey permeate to ethanol is generally not economically feasible because the low lactose content results in low ethanol titre $(2-3 \% \mathrm{v} / \mathrm{v})$, making the distillation process too expensive. Thus, it is important to start the fermentation with high concentration of lactose, which can be achieved by concentrating the whey, e.g. by ultrafiltration and/or reverse osmosis processes, in order to obtain high ethanol titre at the end of fermentation. Alternatively, the sugar concentration can be increased by mixing the native whey with high-sugar condensed materials such as molasses, although in such sugar mixtures the yeast may exhibit catabolite repression and not be able to consume lactose (Oda and Nakamura, 2009). Besides, fermentation must be fast to maximise the ethanol productivity of the process. Nevertheless, in the design of a process for ethanol production from whey a compromise must be made between maximisation of ethanol titre/productivity and minimisation of residual sugar concentration in the effluent, since the purpose of the process is usually also waste treatment.

During the last 30 years, many authors have addressed the production of ethanol from lactose, mostly referring the yeasts Kluyveromyces fragilis, K. marxianus and C. pseudotropicalis. Indeed, in the most recent edition of The Yeasts, a taxonomic study (Kurtzman and Fell, 1998) these are all reported as synonyms of K. marxianus (Lachance, 1998). $K$. fragilis and K. marxianus have been considered separate species for a long time, but $K$. fragilis is now included in the $K$. marxianus species (Fonseca et al., 2008; Lachance, 1998). C. pseudotropicalis (synonym of Candida kefyr) is the anamorph (asexual) form of $K$. marxianus (Lachance, 1998). Nevertheless, we will hereafter maintain the distinction, using the designation originally given in each report. Besides scientific reports, there are a few cases of industrial plants that produce ethanol from whey or permeate, mostly using Kluyveromyces yeasts. The use of S. cerevisiae for lactose fermentation has also attracted much attention. The initial strategies involved the fermentation of prehydrolysed lactose solutions, i.e. mixtures of glucose and galactose. Furthermore, the construction of lactose-consuming $S$. cerevisiae strains has been attempted by several strategies, such as protoplast fusion, expression of heterologous ß-galactosidases secreted to the extracellular medium or simultaneous expression of the permease and ß-galactosidase of $K$. lactis.
One important difference between Kluyveromyces species and $S$. cerevisiae is glucose repression (also known as catabolite repression; Gancedo, 1998) of galactose utilization. Some mechanisms of glucose repression of the GAL genes are shared by S. cerevisiae and K. lactis but there are also fundamental differences (for an extensive review see Rubio-Texeira, 2005). In fact, the expression of the GAL/LAC genes is not repressed by glucose in all $\mathrm{K}$. lactis strains, and the extent of catabolite repression in glucose-repressible strains is less pronounced than in S. cerevisiae (Rubio-Texeira, 2005). This is expected to be also the case in related species, such as K. marxianus, which are mostly adapted to environments containing lactose and galactose. The characteristics of the GAL genes promoters likely contribute to the less pronounced glucose repression of galactose utilization in $K$. lactis compared to $S$. cerevisiae. First, there are several binding sites for the glucose-triggered transcriptional repressor Mig1p in the $S$. cerevisiae GAL promoters, while in $K$. lactis there is only one corresponding binding site (in the GAL1 promoter) (Rubio-Texeira, 2005). Moreover, in $K$. lactis the expression of the GAL4 gene is autoregulated, since its promoter contains a binding site to its own gene product, Gal4p, which encodes a transcriptional activator involved in the regulation of the GAL genes. Conversely, the S. cerevisiae GAL4 promoter does not have any Gal4p binding site (Rubio-Texeira, 2005). Increased dosages of the activator Gal4p in K. lactis may alleviate glucose repression.

\subsection{Kluyveromyces spp.}

$K$. lactis is one of the most studied yeast species and has become a model system for studies on molecular physiology of so-called "nonconventional yeasts", in particular comparative studies with $S$. cerevisiae (Breunig et al., 2000). The interest around $\mathrm{K}$. lactis, namely regarding its lactose metabolism, was initially motivated by academic questions while biotechnological interest came much later (Fukuhara, 2006). $K$. lactis is not commonly used for ethanol production, although it has been exploited for other biotechnological applications such as the production of heterologous proteins (for a review see van Ooyen et al., 2006) namely using cheese whey as culture media (Maullu et al., 1999). The ability of this yeast to metabolise lactose results from the presence of a lactose permease (encoded by the LAC12 gene) and a $\beta$-galactosidase (LAC4 gene) (Rubio-Texeira, 2006). $\beta$-galactosidase hydrolyses lactose into glucose and galactose. Intracellular glucose can enter glycolysis while galactose follows the Leloir pathway. The metabolism of lactose and galactose are closely related. The GAL/LAC system of $K$. lactis has been studied in detail (for reviews see Breunig et al., 2000; Rubio-Texeira, 2005; Schaffrath and Breunig, 2000), particularly in comparison with the model GAL/MEL regulon of $S$. cerevisiae.

Although $K$. lactis is considered the model organism in the Kluyveromyces genus, K. marxianus has received much attention regarding its biotechnological potential, motivated by some advantages that it has when compared to K. lactis (Ribeiro et al., 2007; Fonseca et al., 2008). K. marxianus isolates have originated from an enormous variety of habitats, accounting for the species broad metabolic diversity and consequent wide range of biotechnological applications (Fonseca et al., 2008). Although accumulated knowledge on K. marxianus is much smaller and spread over many different strains, as opposed to $K$. lactis, a considerable number of studies addressing biochemical, metabolic and physiological aspects of $K$. marxianus can be already found in the literature (for a review see Fonseca et al., 2008).

There are numerous reports of lactose/whey alcoholic fermentation using Kluyveromyces yeasts. The vast majority of such reports mention the species $K$. marxianus and $K$. fragilis, which are currently synonyms (see above).

Many authors have reported inhibitory effects and associated problems in the fermentation of concentrated lactose/whey media, particularly slow fermentations and high residual sugar when the initial lactose concentration is increased above 100 to $150 \mathrm{~g} \mathrm{~L}^{-1}$, or in some cases above $200 \mathrm{~g} \mathrm{~L}^{-1}$ (Dale et al., 1994; Gawel and Kosikowski, 
1978; Grubb and Mawson, 1993; Janssens et al., 1983; Kamini and Gunasekaran, 1987; Ozmihci and Kargi, 2007c, d, e; Silveira et al., 2005; Vienne and von Stockar, 1985; Zafar et al., 2005). These problems have been commonly attributed to osmotic sensitivity (due to the high lactose concentrations) and low ethanol tolerance (Grubb and Mawson, 1993; Janssens et al., 1983; Vienne and von Stockar, 1985; Zafar et al., 2005), as well as inhibition by high salts concentration (Grubb and Mawson, 1993). The extent of such effects seems to be strain-dependent, although the fermentation conditions, in particular oxygen and other nutrients availability, may as well play a key role in this regard. The implementation of fed-batch fermentation systems may help circumvent the substrate (lactose and salts) inhibition problems (Ozmihci and Kargi, 2007d), while ethanol inhibition may be alleviated by nutritional supplementation of the medium (Janssens et al., 1983). Alternatively, strain development programmes may generate robust yeast strains with enhanced tolerance towards osmotic and/or ethanol stresses. Such programmes may involve the selection of naturally stress-tolerant isolates and/or metabolic engineering for constructing strains with improved tolerance.

Limitation in the whey nutrient content has been a concern, especially when fermenting high concentrations of lactose. Janssens et al. (1983) reported a strong improvement in the fermentation ability of $K$. fragilis when concentrated whey (200 $\mathrm{g} \mathrm{L}^{-1}$ lactose) already supplemented with $0.5 \%$ bacto-peptone was further supplemented with ergosterol and linoleic acid in Tween 80. Such lipid addition resulted in a decrease in fermentation time from over $90 \mathrm{~h}$ to less than $60 \mathrm{~h}$. The exogenous lipids were taken up by the yeast and probably incorporated in the cell membrane, which is in accordance with the importance of sterols and unsaturated fatty acids for yeast fermentative performance and ethanol tolerance (Aguilera et al., 2006; Casey and Ingledew, 1986; Guimarães et al., 2006; You et al., 2003). Other supplementations tested include ammonium sulphate, urea or peptone (Mahmoud and Kosikowski, 1982), yeast extract, vitamins and minerals (Vienne and von Stockar, 1985) and $\mathrm{NH}_{4} \mathrm{Cl}$ and $\mathrm{KH}_{2} \mathrm{PO}_{4}$ salts (Kargi and Ozmihci, 2006).

The oxygen availability is another key factor affecting yeast performance during fermentation. The oxygen supply must be sufficient to meet the requirement for the biosynthesis of membrane lipids (sterols and unsaturated fatty acids), without causing excessive yeast growth that may reduce the ethanol yield. Silveira et al. (2005) investigated the effect of oxygen level in the fermentation of whey permeate (with lactose concentrations ranging between 1 and $240 \mathrm{~g} \mathrm{~L}^{-1}$ ) by $K$. marxianus. Low oxygen levels favoured fermentative metabolism, leading to higher ethanol volumetric productivities in hypoxic, followed by anoxic and then aerobic conditions. The maximum ethanol concentrations produced and the ethanol yields on lactose were higher in anoxic and hypoxic conditions than in aerobic conditions. Other previous studies have also addressed the influence of oxygen on the patterns of energy metabolism of $K$. marxianus cultivated in lactose (Castrillo et al., 1996; Castrillo and Ugalde, 1993). Similarly, the distribution between respiratory and fermentative metabolism in $K$. lactis has also been intensively studied particularly in respect to the effect of oxygen availability (Breunig et al., 2000; Goffrini et al., 2002; Siso et al., 1996; Snoek and Steensma, 2006).

One significant advantage of some $K$. marxianus strains consists in their ability to grow and ferment at elevated temperatures $\left(>40{ }^{\circ} \mathrm{C}\right)$, a property that enables cost savings (mainly due to reduced cooling cost) in ethanol production bioprocesses (Fonseca et al., 2008). Thermotolerant $K$. marxianus strains have been reported to be capable of growing aerobically at $52{ }^{\circ} \mathrm{C}$ on lactose and whey permeate (Banat and Marchant, 1995). One of such strains (IMB3) was shown to produce ethanol from lactose media at $45^{\circ} \mathrm{C}$ (Brady et al., 1994, 1995; Brady et al., 1997; Kourkoutas et al., 2002a). Recently, Nonklang et al. (2008) reported a thermotolerant $K$. marxianus strain that produced significant amounts of ethanol at $45^{\circ} \mathrm{C}$ from glucose but not from lactose media.

Most studies of lactose/whey fermentation with Kluyveromyces spp. have been done in batch systems (Bothast et al., 1986; Castrillo et al., 1996; Gawel and Kosikowski, 1978; Grubb and Mawson, 1993; Janssens et al., 1983; Kargi and Ozmihci, 2006; Kourkoutas et al., 2002a; Longhi et al., 2004; Ozmihci and Kargi, 2007a, e; Silveira et al., 2005; Zafar and Owais, 2006; Zafar et al., 2005). Nevertheless, continuous operation systems have also been widely exploited using different bioreactor designs and, in most cases, using yeast immobilization strategies for obtaining high cell-densities (Cheryan and Mehaia, 1983; Gianetto et al., 1986; Hahn-Hägerdal, 1985; Janssens et al., 1984; Kleine et al., 1995; Linko et al., 1981; Ozmihci and Kargi, 2007b, c, 2008; Teixeira et al., 1990). Some authors have as well reported fed-batch fermentation systems (Ferrari et al., 1994; Grba et al., 2002; Ozmihci and Kargi, 2007d). Table 1 outlines a compilation of the ethanol volumetric productivities and maximum ethanol titres calculated from the data shown in some of the studies on lactose/whey fermentation by Kluyveromyces yeasts.

The development of kinetic models to describe fermentation of lactose/whey by Kluyveromyces spp. has received considerable attention (Castrillo and Ugalde, 1993; Longhi et al., 2004; Ozmihci and Kargi, 2007b, e; Wang and Bajpai, 1997a, b; Zafar et al., 2005; Zertuche and Zall, 1985). Such mathematical models are essential tools for the optimization and industrial implementation of fermentation systems.

Improvements in lactose fermentation by using Kluyveromyces yeasts in co-culture with lactose-negative microorganisms have been reported, particularly with S. cerevisiae (Guo et al., 2010) and with the ethanologenic bacteria Zymomonas mobilis (Gunasekaran and Kamini, 1991; Kamini and Gunasekaran, 1987, 1989).

Besides potable ethanol, the production of alcoholic beverages from whey has also been pointed as an alternative (Holsinger et al., 1974), including whey wines (Kosikowski, 1979; Kosikowski and Wzorek, 1977), low alcohol content drinks (Kourkoutas et al., 2002a; Kourkoutas et al., 2002b) and distilled drinks (Dragone et al., 2009).

\subsection{C. pseudotropicalis (C. kefyr)}

Some studies have selected $C$. pseudotropicalis strains as the most efficient microorganisms for the conversion of lactose/whey to ethanol among lactose-fermenting yeasts (Ghaly and El-Taweel, 1995b; Izaguirre and Castillo, 1982; Szczodrak et al., 1997). Similarly to reported for Kluyveromyces spp., C. pseudotropicalis strains are inhibited by high lactose concentrations and ethanol (Ghaly and El-Taweel, 1995a; Moulin et al., 1980, 1981; Szczodrak et al., 1997). Ghaly and ElTaweel selected C. pseudotropicalis ATCC 8619 among nine lactosefermenting yeasts (Ghaly and El-Taweel, 1995b). These authors have investigated several aspects of whey fermentations using this strain, namely the effect of nutrient (ammonium sulphate, dipotassium hydrogen phosphate and yeast extract) supplementation (Ghaly and ElTaweel, 1995b) and the effect of increasing lactose concentration (50 to $200 \mathrm{~g} \mathrm{~L}^{-1}$ ) and micro-aeration ( 0.05 to 0.15 v.v.m.) in batch fermentations (Ghaly and El-Taweel, 1995a). Furthermore, they have tested the strain in a continuous fermentation system with feed lactose concentrations ranging from 50 to $150 \mathrm{~g} \mathrm{~L}^{-1}$ and retention times varying between 18 and $42 \mathrm{~h}$ (Ghaly and El-Taweel, 1997a), using the data to develop a kinetic model (Ghaly and El-Taweel, 1997b). C. pseudotropicalis strains have also been used in other systems for ethanol production from lactose/whey, including extractive fermentation (Jones et al., 1993) and coupled fermentation-pervaporation processes (Shabtai and Mandel, 1993). The ethanol volumetric productivities and maximum ethanol titres obtained in selected studies on lactose/whey fermentation by C. pseudotropicalis are shown in Table 1 .

\subsection{Saccharomyces cerevisiae}

S. cerevisiae is usually the first choice for industrial processes involving alcoholic fermentation. The reasons for this preference include: (1) its good fermentative capacity and ethanol tolerance, allowing to produce up to $20 \%$ (v/v) ethanol (Antoni et al., 2007; Cot 
Table 1

Studies on ethanol production from lactose/whey media by Kluyveromyces spp. and Candida pseudotropicalis.

\begin{tabular}{|c|c|c|c|c|c|}
\hline Organism & Media & Bioreactor/operation type & $\begin{array}{l}\text { Ethanol } \\
\text { productivity } \\
\left(\mathrm{g} \cdot \mathrm{L} \cdot \mathrm{h}^{-1}\right)\end{array}$ & $\begin{array}{l}\text { Ethanol } \\
\text { titre } \\
\left(\mathrm{g} \cdot \mathrm{L}^{-1}\right)\end{array}$ & Reference \\
\hline Kluyveromyces fragilis & Concentrated whey permeate ( $24 \%$ lactose) & $\begin{array}{l}\text { Batch (static } 3 \mathrm{~L} \text { bottles capped } \\
\text { by air locks filled with glycerol) }\end{array}$ & 0.2 & 80 & Gawel and Kosikowski (1978) \\
\hline K. fragilis & $\begin{array}{l}\text { Concentrated whey permeate ( } 24 \% \text { lactose) } \\
\text { with reduced ash }\end{array}$ & 14 L Bioreactor/Batch & 0.6 & 72 & $\begin{array}{l}\text { Mahmoud and Kosikowski } \\
\text { (1982) }\end{array}$ \\
\hline \multirow[t]{5}{*}{ K. fragilis } & $\begin{array}{l}\text { Rich media (peptone, yeast extract, } \\
\text { malt extract) }\end{array}$ & $\begin{array}{l}\text { Membrane recycle bioreactor } \\
\text { system (very high cell density) }\end{array}$ & & & Cheryan and Mehaia (1983) \\
\hline & $5 \%$ lactose & Batch & 3.0 & 23 & \\
\hline & $5 \%$ lactose & Continuous & 65 & 10 & \\
\hline & $15 \%$ lactose & Continuous & 70 & 70 & \\
\hline & $15 \%$ lactose & Continuous & 240 & 40 & \\
\hline \multirow[t]{3}{*}{ K. fragilis } & Deproteinised whey powder $+0.5 \%$ peptone & $\begin{array}{l}\text { Batch ( } 1 \text { L stirred flasks fitted } \\
\text { with water traps) }\end{array}$ & & & Janssens et al. (1983) \\
\hline & (15\% lactose, no lipid supplements) & & 2.0 & 71 & \\
\hline & $\begin{array}{l}\text { ( } 20 \% \text { lactose, medium supplemented with } \\
\text { ergosterol, linoleic acid and Tween } 80 \text { ) }\end{array}$ & & 1.4 & 86 & \\
\hline K. fragilis & $\begin{array}{l}\text { Deproteinised whey powder }+0.5 \% \text { peptone } \\
\text { (10\% lactose) }\end{array}$ & $\begin{array}{l}6 \text { L Bioreactor/Continuous } \\
\text { process with cell recycling }\end{array}$ & 7.1 & 47 & Janssens et al. (1984) \\
\hline $\begin{array}{l}\text { K. fragilis immobilized } \\
\text { in calcium alginate }\end{array}$ & Concentrated whey permeate ( $15 \%$ lactose) & Packed-bed column/Continuous & 1.1 & 13 & Hahn-Hägerdal (1985) \\
\hline K. fragilis & Yeast extract/Peptone/Lactose (YPL) & 0.3 L Bioreactor/Fed-batch & 1.5 & 80 & Farahnak et al. (1986) \\
\hline $\begin{array}{l}\text { K. fragilis immobilized } \\
\text { in charcoal pellets }\end{array}$ & Concentrated whey solution ( $15 \%$ lactose) & Tubular reactor/Continuous & 17.2 & 18 & Gianetto et al. (1986) \\
\hline \multirow[t]{3}{*}{ Kluyveromyces marxianus } & Semi-synthetic medium & $\begin{array}{l}1.2 \text { L Air-lift bioreactor } \\
\text { (external loop)/Continuous }\end{array}$ & & & Teixeira et al. (1990) \\
\hline & (5.7\% lactose) & & 24.4 & 29 & \\
\hline & (9.4\% lactose) & & 15.2 & 45 & \\
\hline K. fragilis, free cells & Complete medium (20\% lactose) & Batch & 0.74 & 53 & $\begin{array}{l}\text { Gunasekaran and Kamini } \\
\text { (1991) }\end{array}$ \\
\hline $\begin{array}{l}\text { K. fragilis immobilized } \\
\text { in calcium alginate }\end{array}$ & Complete medium (20\% lactose) & Batch & 0.88 & 63 & \\
\hline $\begin{array}{l}\text { Mix of } K \text {. fragilis and } Z \text {. mobilis } \\
\text { immobilized in calcium alginate }\end{array}$ & Complete medium (20\% lactose) & Batch & 1.0 & 72 & \\
\hline K. fragilis & Semi-synthetic medium (20\% lactose) & 20 L Bioreactor/Batch & 2.1 & 72 & Ryu et al. (1991) \\
\hline K. fragilis & Concentrated whey permeate ( $10 \%$ lactose) & Fed-batch & 3.3 & 64 & Ferrari et al. (1994) \\
\hline $\begin{array}{l}\text { K. fragilis immobilized in } \\
\text { plant material }\end{array}$ & Deproteinised whey (5.5\% lactose) & Fluidized-bed reactor/Continuous & 14.5 & 20 & Kleine et al. (1995) \\
\hline K. marxianus & $\begin{array}{l}\text { Deproteinised whey }+ \text { yeast extract and salts } \\
(6.5 \% \text { lactose })\end{array}$ & 5 L Bioreactor/Batch & 0.52 & 26 & Rosenberg et al. (1995) \\
\hline \multirow[t]{2}{*}{ K. marxianus } & $\begin{array}{l}\text { Deproteinised whey }+ \text { yeast extract and salts } \\
\text { (10\% lactose) }\end{array}$ & 2 L Bioreactor/Batch & 3.1 & 43 & Grba et al. (2002) \\
\hline & & 2 L Bioreactor/Fed-batch & 4.9 & 59 & \\
\hline K. marxianus & Whey permeate solution ( $17 \%$ lactose) & $\begin{array}{l}\text { Batch ( } 1 \text { L stirred flasks) } \\
\text { Hypoxic and anoxic conditions }\end{array}$ & $1.0-1.5$ & $76-80$ & Silveira et al. (2005) \\
\hline K. marxianus & $\begin{array}{l}\text { Concentrated whey powder solution } \\
\text { (15\% lactose) }\end{array}$ & Shake-flasks & 0.4 & 80 & Kargi and Ozmihci (2006) \\
\hline K. marxianus & $\begin{array}{l}\text { Concentrated whey powder solution } \\
\text { (10\% lactose) }\end{array}$ & 5 L Bioreactor/Continuous & 0.74 & 32 & Ozmihci and Kargi (2007b) \\
\hline K. marxianus & $\begin{array}{l}\text { Concentrated whey powder solution } \\
\text { (10-12.5\% lactose) }\end{array}$ & 5 L Bioreactor/Continuous & 0.54 & 29 & Ozmihci and Kargi (2007c) \\
\hline K. marxianus & $\begin{array}{l}\text { Concentrated whey powder solution } \\
\text { (12.5\% lactose) }\end{array}$ & $\begin{array}{l}5 \text { L Bioreactor/Repeated } \\
\text { Fed-batch operation }\end{array}$ & 5.3 & 63 & Ozmihci and Kargi (2007d) \\
\hline K. marxianus & $\begin{array}{l}\text { Concentrated whey powder solution } \\
\text { (7.5\% lactose) }\end{array}$ & Shake-flasks & 0.55 & 40 & Ozmihci and Kargi (2007e) \\
\hline $\begin{array}{l}\text { K. marxianus immobilized } \\
\text { in olive pits }\end{array}$ & Whey powder solution (5\% lactose) & Packed-bed column/Continuous & 0.4 & 20 & Ozmihci and Kargi (2008) \\
\hline $\begin{array}{l}\text { Mix of } K \text {. marxianus and S. cerevisiae } \\
\text { immobilized in calcium alginate }\end{array}$ & $\begin{array}{l}\text { Concentrated whey powder solution } \\
\text { (10\% lactose) }\end{array}$ & $\begin{array}{l}\text { Shake-flasks } \\
\text { (in an anaerobic shaker) }\end{array}$ & 0.88 & 42 & Guo et al., 2010 \\
\hline Candida pseudotropicalis & $\begin{array}{l}\text { Cheese whey + reagent grade lactose } \\
(10-20 \% \text { lactose) }\end{array}$ & 5 L Bioreactor/Batch & $0.7-1.0$ & $40-45$ & Ghaly and El-Taweel (1995a) \\
\hline C. pseudotropicalis & $\begin{array}{l}\text { Cheese whey + yeast extract + lactose } \\
\text { (to } 15 \% \text { ) }\end{array}$ & 5 L Bioreactor/Continuous & 1.4 & 58 & $\begin{array}{l}\text { Ghaly and El-Taweel } \\
(1997 a, b)\end{array}$ \\
\hline \multirow[t]{2}{*}{ C. pseudotropicalis } & Semi-synthetic medium (12\% lactose) & Shake-flasks & 1.2 & 58 & Szczodrak et al. (1997) \\
\hline & Deproteinized whey (10\% lactose) & Shake-flasks & 0.85 & 41 & \\
\hline
\end{tabular}

et al., 2007); (2) its GRAS (generally regarded as safe) status; (3) its capacity to grow rapidly under anaerobic conditions, which helps circumventing the oxygenation problems inherent to large-volume industrial fermentations (Snoek and Steensma, 2007); (4) the extensive industrial and scientific knowledge accumulated that makes it one of the best studied organisms; (5) the possibility to use its biomass as animal feed (co-product), which is important for industrial process economics (Bai et al., 2008). However, wild S. cerevisiae strains are unable to metabolise lactose. Nevertheless, S. cerevisiae can utilize galactose, which is taken up by a permease encoded by the gene GAL2 (Nehlin et al., 1989). Once inside the cell, catabolism of galactose proceeds through the Leloir pathway.

Thus, the first applications of $S$. cerevisiae in whey fermentations involved the pre-hydrolysis of lactose and further fermentation of 
the resulting mixture of glucose and galactose. There are two main drawbacks associated with such strategy. On the one hand, it requires a lactose hydrolysis step, most often an enzymatic process using ß-galactosidase. On the other hand, due to the catabolite repression phenomenon (Gancedo, 1998), S. cerevisiae consumes glucose preferentially to galactose, resulting, in most cases, in prolonged fermentations with a diauxic lag after glucose exhaustion and before galactose fermentation, which is, in general, rather slow (Mehaia and Cheryan, 1990; O'Leary et al., 1977). In an attempt to circumvent this later problem, Bailey et al. (1982) used 2-deoxyglucose as a selection agent to isolate catabolite repression-resistant mutants of an industrial S. cerevisiae strain, which were capable of utilizing glucose and galactose simultaneously. One of those mutants (strain SR), fermented completely a mixture of $10 \%$ glucose plus $10 \%$ galactose in less than $37 \mathrm{~h}$, producing about $90 \mathrm{~g} \mathrm{~L}^{-1}$ of ethanol (Table 2). This mutant was also tested in a continuous fermentation system with cell recycling, attaining an ethanol productivity of $13.6 \mathrm{~g} \mathrm{~L}^{-1} \mathrm{~h}^{-1}$ from feed medium containing an equimolar mixture of glucose and galactose (15\% total sugar) under conditions permitting a residual sugar concentration below $1 \%$ (Terrell et al., 1984) (Table 2). Recently, Oda and Nakamura (2009) have also isolated 2-deoxyglucose-resistant mutants of $K$. marxianus. One of those mutants (KD-15) was able to produce ethanol from a mixture of beet molasses (containing sucrose) and cheese whey, proving to be insensitive to catabolite repression in contrast to the parental strain (NBRC 1963).

Some authors have proposed the use of a biocatalyst consisting of ß-galactosidase co-immobilized with S. cerevisiae cells as an alternative for whey fermentations (Hahn-Hägerdal, 1985; Roukas and Lazarides, 1991). Hahn-Hägerdal (1985) reported that S. cerevisiae co-immobilized with ß-galactosidase in calcium alginate yielded higher ethanol titre
(52 $\mathrm{g} \mathrm{L}^{-1}$ ) and productivity $\left(4.5 \mathrm{~g} \mathrm{~L}^{-1} \mathrm{~h}^{-1}\right)$ in continuous concentrated whey (15\% substrate) fermentation, as compared to immobilized $K$. fragilis cells (ethanol titre of $13 \mathrm{~g} \mathrm{~L}^{-1}$ and productivity of $1.1 \mathrm{~g} \mathrm{~L}^{-1} \mathrm{~h}^{-1}$ ) (Tables 1 and 2). A similar biocatalyst has been applied in a hybrid system coupling whey fermentation with a pervaporation module for ethanol separation (Lewandowska and Kujawski, 2007; Staniszewski et al., 2009). Rosenberg et al. (1995) used permeabilized K. marxianus cells as the source of ß-galactosidase for simultaneous hydrolysis of lactose in concentrated whey and fermentation by S. cerevisiae, obtaining enhanced ethanol productivity as compared to direct fermentation using K. marxianus (see Tables 1 and 2).

One of the first approaches to create $\mathrm{Lac}^{+}$(lactose-consuming) $S$. cerevisiae consisted in the generation of hybrid strains with Kluyveromyces spp. by protoplast fusion. Taya et al. (1984) obtained a stable hybrid between polyploid strains of saké yeast (S. cerevisiae) and $K$. lactis. The fusant was able to ferment lactose, producing more ethanol and at higher rate than the K. lactis parental strain. Farahnak et al. (1986) obtained fusants between $S$. cerevisiae and $K$. fragilis, one of which was capable of producing about $13 \%(\mathrm{v} / \mathrm{v})$ ethanol in YP medium to which lactose was fed periodically, while the parent $K$. fragilis strain produced only about $10 \%(\mathrm{v} / \mathrm{v}$ ) ethanol (Tables 1 and 2). Ryu et al. (1991) also constructed a $S$. cerevisiae- $K$. fragilis fusant whose lactose fermentation performance was better than the $K$. fragilis parental strain (Tables 1 and 2). Moreover, the ethanol tolerance of the fusant was increased as compared to $K$. fragilis, which was attributed to a higher unsaturated fatty acids content, particularly linoleic acid (Ryu et al., 1991). More recently, protoplasts fusion was also used to produce hybrids of S. cerevisiae and $K$. lactis that proved able to ferment lactose in sweet and salted whey (Tahoun et al., 1999, 2002).

Table 2

Studies on ethanol production from lactose/whey media by Saccharomyces cerevisiae.

\begin{tabular}{|c|c|c|c|c|c|}
\hline Organism & Media & Bioreactor/operation type & $\begin{array}{l}\text { Ethanol } \\
\text { productivity } \\
\left(\mathrm{g} \cdot \mathrm{L} \cdot \mathrm{h}^{-1}\right)\end{array}$ & $\begin{array}{l}\text { Ethanol } \\
\text { titre } \\
\left(\mathrm{g} \cdot \mathrm{L}^{-1}\right)\end{array}$ & Reference \\
\hline $\begin{array}{l}\text { S. cerevisiae (catabolite } \\
\text { repression-resistant mutant) }\end{array}$ & $\begin{array}{l}\text { Rich medium containing glucose/galactose } \\
\text { mixtures (equivalent to } 20 \% \text { lactose hydrolysate) }\end{array}$ & $\begin{array}{l}\text { Batch ( } 0.5 \mathrm{~L} \text { stirred flasks } \\
\text { fitted with water traps) }\end{array}$ & 2.3 & 90 & Bailey et al. (1982) \\
\hline $\begin{array}{l}\text { S. cerevisiae (catabolite } \\
\text { repression-resistant mutant) }\end{array}$ & $\begin{array}{l}\text { Rich medium containing glucose/galactose } \\
\text { mixtures (equivalent to 15\% lactose hydrolysate) }\end{array}$ & $\begin{array}{l}6 \mathrm{~L} \text { Bioreactor/Continuous } \\
\text { process with cell recycling }\end{array}$ & 13.6 & 70 & Terrell et al. (1984) \\
\hline $\begin{array}{l}\text { S. cerevisiae co-immobilised } \\
\text { with ß-galactosidase }\end{array}$ & Concentrated whey permeate ( $15 \%$ lactose) & Packed-bed column/Continuous & 4.5 & 52 & Hahn-Hägerdal (1985) \\
\hline $\begin{array}{l}\text { S. cerevisiae-K.fragilis hybrid } \\
\text { (protoplast fusion) }\end{array}$ & Yeast extract/Peptone/Lactose (YPL) & 0.3 L Bioreactor/Fed-batch & 1.3 & 105 & Farahnak et al. (1986) \\
\hline $\begin{array}{l}\text { S. cerevisiae-K.fragilis hybrid } \\
\text { (protoplast fusion) }\end{array}$ & Semi-synthetic medium (20\% lactose) & 20 L Bioreactor/Batch & 2.4 & 82 & Ryu et al. (1991) \\
\hline $\begin{array}{l}\text { Autolytic } S \text {. cerevisiae } \\
\text { expressing E. coli lacZ }\end{array}$ & Yeast Nitrogen Base/Lactose & Shake-flasks & $0.1-0.2$ & 18 & Porro et al. (1992b) \\
\hline $\begin{array}{l}\text { S. cerevisiae secreting } \\
\text { A.niger } \beta \text {-galactosidase }\end{array}$ & YPL; synthetic lactose medium & Shake-flasks; 2 L Bioreactor/Batch & $0.14-0.6$ & 30 & $\begin{array}{l}\text { Ramakrishnan and } \\
\text { Hartley (1993) }\end{array}$ \\
\hline $\begin{array}{l}\text { Autolytic S. cerevisiae } \\
\text { expressing E. coli lacZ }\end{array}$ & YPL + whey & 2 L Bioreactor/Batch/Fed-batch & 1.0 & 9 & Compagno et al. (1995) \\
\hline $\begin{array}{l}\text { S. cerevisiae plus permeabilized } \\
\text { K. marxianus }\end{array}$ & $\begin{array}{l}\text { Deproteinised whey }+ \text { yeast extract and } \\
\text { salts ( } 6.5 \% \text { lactose) }\end{array}$ & 5 L Bioreactor/Batch & 1.0 & 30 & Rosenberg et al. (1995) \\
\hline $\begin{array}{l}\text { S. cerevisiae expressing } \\
\text { K. lactis LAC4 and LAC12 }\end{array}$ & Synthetic lactose $(2.2 \%)$ medium & 2 L Bioreactor/Batch & 0.3 & 4 & Rubio-Texeira et al. (1998) \\
\hline \multirow{2}{*}{$\begin{array}{l}\text { S. cerevisiae expressing } \\
\text { K. lactis LAC4 and LAC12 }\end{array}$} & Semi-synthetic lactose $(5 \%)$ medium & Shake-flasks & 0.45 & 16 & Domingues et al. (1999a) \\
\hline & & 6 L Air-lift bioreactor/Continuous & 11.0 & 20 & \\
\hline \multirow{4}{*}{$\begin{array}{l}\text { S. cerevisiae expressing } \\
\text { K. lactis LAC4 and LAC12 }\end{array}$} & Cheese whey permeate & & & & Domingues et al. (2001) \\
\hline & (5\% lactose) & Shake-flasks & 0.68 & 21 & \\
\hline & (10\% lactose) & 2 L Bioreactor/Batch & 1.8 & 53 & \\
\hline & (5\% lactose) & 6 L Air-lift bioreactor/Continuous & 10.0 & 20 & \\
\hline $\begin{array}{l}\text { S. cerevisiae secreting } \\
\text { A.niger } \beta \text {-galactosidase }\end{array}$ & Semi-synthetic lactose (5\%) medium & 2 L Bioreactor/Batch & 1.0 & 25 & Domingues et al. (2002) \\
\hline $\begin{array}{l}\text { S. cerevisiae secreting } \\
\text { A.niger } \beta \text {-galactosidase }\end{array}$ & Semi-synthetic lactose $(5 \%)$ medium & 6 L Air-lift bioreactor/Continuous & 9.0 & 20 & Domingues et al. (2005) \\
\hline $\begin{array}{l}\text { S. cerevisiae expressing } \\
\text { K. lactis LAC4 and LAC12 }\end{array}$ & $\begin{array}{l}\text { Concentrated whey powder solution } \\
\text { (15\% lactose) }\end{array}$ & 2 L Bioreactor/Batch & 0.46 & 55 & Guimarães et al. (2008a) \\
\hline $\begin{array}{l}\text { S. cerevisiae expressing } \\
\text { K. lactis LAC4 and LAC12 }\end{array}$ & $\begin{array}{l}\text { Buffered defined mineral medium } \\
\text { (15\% lactose) }\end{array}$ & Shake-flasks & $1.5-2.0$ & 63 & Guimarães et al. (2008c) \\
\hline
\end{tabular}


The possibility of gene transfer using recombinant DNA technology opened new opportunities to enlarge the spectrum of sugars that can be metabolised by S. cerevisiae. Efforts were therefore made to endow $S$. cerevisiae strains with the ability to ferment lactose. One of the strategies consisted in the construction of recombinant S. cerevisiae strains that secrete $\beta$-galactosidase to the medium. This approach allows production of the enzyme, which may be recovered from the cultivation broth, along with lactose fermentation. The extracellular $\beta$-galactosidase from $A$. niger (gene lacA) has been particularly exploited in this respect (Kumar et al., 1992; Ramakrishnan and Hartley, 1993), namely by our research group (Domingues et al., 2005; Domingues et al., 2004; Domingues et al., 2000a; Domingues et al., 2002; Oliveira et al., 2007). We have constructed flocculent $S$. cerevisiae strains that express the gene lacA from episomal plasmids (Domingues et al., 2000a; Domingues et al., 2002) or in which the gene was integrated in the genome (Oliveira et al., 2007). Together with the secretion of high amounts of $\beta$-galactosidase, these strains produced ethanol from lactose with close to theoretical yields in batch (Domingues et al., 2002) and continuous (Domingues et al., 2005) fermentations (Table 2). S. cerevisiae expressing and secreting K. lactis $\beta$-galactosidase have also been reported (Becerra et al., 2001b; Becerra et al., 2001c). In addition, strategies based on the release of intracellular heterologous $\beta$-galactosidase (e.g. from E. coli or K. lactis) by other means than secretion have been designed. One of those strategies consisted in the transformation of $S$. cerevisiae with a multicopy expression vector bearing both the $\beta$-galactosidase gene from E. coli (LaCZ) and the S. cerevisiae GAL4 gene (Compagno et al., 1995; Porro et al., 1992b). The overproduction of Gal4p caused lysis of a fraction of the cells, resulting in the release of $\beta$-galactosidase into the medium (Porro et al., 1992b). The authors have further characterized this GAL4-induced cell lysis phenomenon, showing that lysis was preceded by a loss of the plasma membrane integrity and occurred in a specific subpopulation of cells (the parent cells), independently of the genealogical age, growth phase conditions and cell cycle progression (Martegani et al., 1993). Other approaches used to achieve controlled release of $\beta$-galactosidase to the medium include the use of thermosensitive autolytic mutants (Becerra et al., 1997; Becerra et al., 2004) and cell permeabilization with toluene or ethanol (Compagno et al., 1993). A strain secreting E. coli $\beta$-galactosidase to the periplasmic space was also reported (Porro et al., 1992a). The main disadvantage of these extracellular hydrolysis approaches is the potential catabolite repression problem associated with the utilization of glucose-galactose mixtures as aforementioned. Interestingly, the strain constructed by Porro et al. (1992b) did not display diauxic growth. These authors have attributed the ability of the strain to consume simultaneously glucose and galactose to the overproduction of Gal4p, since this regulatory protein is also involved in the glucose repression of the GAL genes (see above) and their preliminary experiments suggested that high overexpression of GAL4 caused a derepressed phenotype (Porro et al., 1992b).

The alternative strategy involves the simultaneous expression in S. cerevisiae of a lactose permease and an intracellular $\beta$-galactosidase. The Kluyveromyces systems, in particular LAC12 and LAC4 genes of $K$. lactis, are a logical choice due to the phylogenetic proximity between the two species. Sreekrishna and Dickson (1985) were the first to construct $\mathrm{Lac}^{+}$S. cerevisiae strains by transfer of the LAC12 and LAC4 genes of $K$. lactis, but the transformants obtained grew slowly in lactose (doubling time in lactose minimal media of $6.7 \mathrm{~h}$; Sreekrishna and Dickson, 1985). Rubio-Texeira et al. (1998) engineered a fastgrowing $\mathrm{Lac}^{+}$diploid S. cerevisiae strain expressing the K. lactis LAC12 and $L A C 4$ genes. However, in lactose medium, the recombinant strain obtained exhibited a respiro-fermentative metabolism similar to that of $K$. lactis, with high biomass yield but low ethanol production (Rubio-Texeira et al., 1998) (Table 2).

In our laboratory, a flocculent $S$. cerevisiae $\mathrm{Lac}^{+}$strain expressing LAC12 and LAC4 was constructed (Domingues et al., 1999b). The original recombinant (NCYC869-A3/T1, or simply T1) grew slowly in lactose (doubling time in lactose minimal media of $5 \mathrm{~h}$ ), with low ethanol yield (Domingues et al., 1999b). However, after an adaptation period, where T1 was kept in liquid lactose medium, refreshed periodically, an increase in growth rate and in ethanol specific production rate in lactose was observed. That adapted strain was successfully used in long-term continuous lactose fermentations in air-lift bioreactor (Domingues et al., 1999a; Domingues et al., 2001) resulting in high ethanol productivities from lactose (Table 2). The hydrodynamics and rheology of the flocculated yeast in the bioreactor were studied (Klein et al., 2005). Furthermore, a kinetic model describing lactose fermentation was constructed using data obtained in batch cultivations (Juraščík et al., 2006). Unexpectedly, the strain lost its improved phenotype after storage at $-80^{\circ} \mathrm{C}$ : when the culture was re-grown from $-80^{\circ} \mathrm{C}$ stocks the slow growth in lactose was again observed. Thus, the adaptation period was needed even for an already adapted culture of $\mathrm{T} 1$ that had been kept at $-80^{\circ} \mathrm{C}$ (Domingues et al., 1999b). A stable evolved strain that derived from T1 by a long-term evolutionary engineering experiment was further obtained and named T1-E (Guimarães et al., 2008a). This evolved strain fermented lactose faster with higher ethanol yield than the original recombinant (non-adapted T1), also displaying improved flocculation. Physiological and molecular differences between $\mathrm{T} 1$ and $\mathrm{T} 1-\mathrm{E}$ were investigated (Guimarães et al., 2008a), particularly using transcriptomic analysis (Guimarães et al., 2008b), enlightening some of the underlying mechanisms involved in the evolutionary adaptation of the recombinant to lactose fermentation. Specifically, two molecular events that targeted the $L A C$ construct in the evolved strain were identified: a large (1593 bp) deletion in the intergenic region between LAC4 and LAC12 and a decrease of the plasmid copy number by about 10 -fold compared to that in the original recombinant T1. In K. lactis, the unusually large intergenic region between LAC4 and LAC12 works as the promoter for the divergent transcription of both the $L A C$ genes (Gödecke et al., 1991). Taken together, the experimental results suggested that the intact promoter (endogenous $K$. lactis promoter) was unable to mediate induction by lactose of the transcription of LAC4 and LAC12 in the original recombinant T1, whereas the deletion identified established transcriptional induction of both genes in the evolved recombinant T1-E. It was therefore proposed that tuning of the expression of the heterologous LAC genes in the evolved recombinant was accomplished by interplay between the decreased copy number of both genes and different levels of transcriptional induction for $L A C 4$ and $L A C 12$, resulting from the changed promoter structure (Guimarães et al., 2008a). Besides keeping an improved stable lactose fermentation and highly flocculent phenotype, strain T1-E was able to efficiently ferment high concentrations of lactose to ethanol. In batch fermentations, it produced a maximum of $8 \%$ $(\mathrm{v} / \mathrm{v})$ ethanol from mineral medium with $150 \mathrm{~g} \mathrm{~L}^{-1}$ lactose, with a productivity of $1.5-2.0 \mathrm{~g} \mathrm{~L}^{-1} \mathrm{~h}^{-1}$ (Guimarães et al., 2008c) (Table 2). It was also able to ferment concentrated cheese whey $\left(150 \mathrm{~g} \mathrm{~L}^{-1}\right.$ lactose) producing $7 \%(\mathrm{v} / \mathrm{v})$ ethanol, but the fermentation was much slower and consequently productivity was low $\left(0.46 \mathrm{~g} \mathrm{~L}^{-1} \mathrm{~L}^{-1}\right)$ (Guimarães et al., 2008a) (Table 2). Nevertheless, we have observed that supplementation of the whey with nutrient sources may improve this productivity (unpublished results). The highly flocculent phenotype of the strain makes it particularly interesting for application in high cell density fermentations, which in general result in enhanced process productivity. In continuous systems, particularly with properly designed air-lift bioreactors, the flocculated biomass can be easily accumulated in the bioreactor without the need of immobilisation in a support (Domingues et al., 2000b). In addition, there are a number of other important advantages for the industrial application of flocculating yeasts, namely easy cell recycling for repeated-batch operation and simplification of the downstream processing, since flocculated cells may be easily separated from the fermentation broth by sedimentation at the end of fermentation, as 
well as improved ethanol tolerance and cell viability (Zhao and Bai, 2009).

\subsection{Industrial production of ethanol from whey}

There are a few established industrial processes to produce ethanol from whey, which has been done in some countries, namely Ireland, New Zealand, United States and Denmark (Lyons and Cunningham, 1980; Pesta et al., 2007; Siso, 1996).

Carbery Milk Products (currently designated Carbery Group) from Cork, Ireland, started the operation of an industrial-scale whey-toethanol plant in 1978. The operation was intended for the production of potable ethanol, but since 2005, the company has also been supplying fuel ethanol to a petrol company in Ireland for E85 and E5 blends (Doyle, 2005; Ling, 2008). The pioneer Carbery process was later adopted by plants in New Zealand and the United States (Ling, 2008). Currently, the Carbery plant operates with eleven cylindroconical fermentation vessels, using compressed air for agitation and aeration. The whey permeate is fermented in batch mode for 12 to $20 \mathrm{~h}$, depending on the initial concentration and yeast activity. The yeast is recovered at the end of fermentation and reused a number of times before it is discarded. Ethanol titres at the end of fermentation are typically in the range $2.5-4.2 \%(\mathrm{v} / \mathrm{v})$. Following fermentation, a continuous distillation process is used. It is noteworthy that potable ethanol and fuel ethanol have different quality requirements and therefore there may be some differences in the production process (for short descriptions of the Carbery process see Pesta et al., 2007; Ling, 2008). Carbery produces about 11 thousand tonnes of ethanol per year (Doyle, 2005). Up to 2005, the main markets were beverages, pharmaceutical and industrial (printing inks, etc.) (Doyle, 2009).

In New Zealand, Anchor Ethanol, a subsidiary of the dairy Fonterra Cooperative Group, operates three whey-to-ethanol plants producing around 17 million litres of ethanol per year (Thiele, 2005). Anchor produces eight different ethanol grades, from potable ethanol for beverages to anhydrous alcohol for fuels (Thiele, 2005). The main markets have been pharmaceutical, cosmetics, industrial solvents (including inks) as well as food and beverages, with a substantial proportion of the production being exported (Hamilton, 1998; Thiele, 2005). Since 2007, Anchor has also been supplying fuel ethanol to a petrol company in New Zealand for E10 blend (Ling, 2008). The feedstock is deproteinated whey from casein manufacture or total milk protein production (Hamilton, 1998), which is concentrated from 4\% to $8 \%$ lactose by reverse osmosis prior to fermentation (Gibson, 2006). The concentrate is fermented for about $24 \mathrm{~h}$ using Kluyveromyces spp., attaining an ethanol titre of about $4 \%$, followed by distillation and water removal to different ethanol grades (Gibson, 2006).

In the United States, the Milbrew process was developed in 1972 to produce single-cell protein and ethanol from whey using $K$. fragilis (Detroy and Julian, 1982; Lyons and Cunningham, 1980; Pesta et al., 2007). The ethanol yield could be manipulated by changing the fermentation conditions, such as the aeration rate (Lyons and Cunningham, 1980). At least two other industrial-scale plants have been owned and operated by dairy cooperatives in the United States to produce ethanol from whey (Ling, 2008).

In Denmark, the Dansk Gaerings process was developed in the 1970s for the production of ethanol from whey permeate in a continuous system (Lyons and Cunningham, 1980; Pesta et al., 2007).

Recently, the dairy group Theo Müller announced the construction of a facility in its Leppersdorf plant (Germany) aiming to produce 10 million litres per year of fuel bio-ethanol from whey by-products (Müller, 2009).

\section{Conclusions}

Cheese whey is increasingly recognized has a source of added value products, instead of just a waste stream with a high polluting load. In particular, bioactive whey proteins and peptides are gradually finding more applications not only in food products (including functional foods) but also in the pharmaceutical field. The lactose-rich stream that remains after separation of proteins and other interesting bioactive components is still a major environmental concern and solutions for its valorisation are a need. Since there is a large surplus of lactose, its conversion to bulk commodities such as bio-ethanol needs to be considered as a possible solution, which indeed has been done for many years by dairies in Ireland and New Zealand. Despite some examples of industrial implementation, the fermentation technology must be further improved in order to enhance the attractiveness of whey-to-ethanol bioprocesses. Specifically, although there has been a long research and development effort in this field, there is still the need to develop microbial strains that ferment lactose to ethanol with very high efficiency. The engineering of yeasts, particularly recombinant $S$. cerevisiae strains, for such lactose fermentation processes has achieved promising results, which need now to be scaled-up to provide evidence of industrial significance. Flocculent lactose-fermenting yeast strains can be used to design continuous high cell density fermentation processes with high ethanol productivity. Besides, the better strains obtained so far may be further improved by using the metabolic engineering and systems biology toolboxes that are becoming increasingly widespread. Moreover, such state-of-the-art tools may be used to exploit alternative research lines, for instance for enhancing the ethanol tolerance and lactose-to-ethanol conversion yields of wild lactose-fermenting microorganisms, such as K. marxianus.

\section{Acknowledgements}

The financial support of Fundação para a Ciência e a Tecnologia (FCT), Portugal (project ProBioethanol PTDC/BIO/66151/2006) is acknowledged. P. M. R. Guimarães acknowledges support from FCT, Portugal (grants SFRH/BD/13463/2003 and SFRH/BPD/44328/2008).

\section{References}

Adam AC, Rubio-Texeira M, Polaina J. Lactose: the milk sugar from a biotechnological perspective. Crit Rev Food Sci Nutr 2004;44:553-7.

Aguilera F, Peinado RA, Millan C, Ortega JM, Mauricio JC. Relationship between ethanol tolerance, $\mathrm{H}^{+}$-ATPase activity and the lipid composition of the plasma membrane in different wine yeast strains. Int J Food Microbiol 2006;110:34-42.

Antoni D, Zverlov VV, Schwarz WH. Biofuels from microbes. Appl Microbiol Biotechnol 2007;77:23-35

Audic JL, Chaufer B, Daufin G. Non-food applications of milk components and dairy coproducts: a review. Lait 2003;83:417-38.

Bai FW, Anderson WA, Moo-Young M. Ethanol fermentation technologies from sugar and starch feedstocks. Biotechnol Adv 2008;26:89-105.

Bailey RB, Benitez T, Woodward A. Saccharomyces cerevisiae mutants resistant to catabolite repression: use in cheese whey hydrolysate fermentation. Appl Environ Microbiol 1982;44:631-9.

Banat IM, Marchant R. Characterization and potential industrial applications of five novel, thermotolerant, fermentative, yeast strains. World J Microbiol Biotechnol 1995; 11:304-6

Beaulieu J, Dupont C, Lemieux P. Whey proteins and peptides: beneficial effects on immune health. Therapy 2006;3:69-78.

Becerra M, Rodriguez-Belmonte E, Esperanza Cerdan M, Gonzalez Siso MI. Engineered autolytic yeast strains secreting Kluyveromyces lactis $\beta$-galactosidase for production of heterologous proteins in lactose media. J Biotechnol 2004;109:131-7.

Becerra M, Cerdan E, Siso MIG. Heterologous Kluyveromyces lactis $\beta$-galactosidase production and release by Saccharomyces cerevisiae osmotic-remedial thermosensitive autolytic mutants. Biochim Biophys Acta 1997;1335:235-41.

Becerra M, Baroli B, Fadda AM, Mendez JB, Siso MIG. Lactose bioconversion by calciumalginate immobilization of Kluyveromyces lactis cells. Enzyme Microbiol Technol 2001a;29:506-12.

Becerra M, Prado SD, Cerdán E, Siso MIG. Heterologous Kluyveromyces lactis $\beta$-galactosidase secretion by Saccharomyces cerevisiae super-secreting mutants. Biotechnol Lett 2001b;23:33-40.

Becerra M, Prado SD, Siso MI, Cerdan ME. New secretory strategies for Kluyveromyces lactis $\beta$-galactosidase. Protein Eng 2001c;14:379-86.

Bothast RJ, Kurtzman CP, Saltarelli MD, Slininger PJ. Ethanol production by 107 strains of yeasts on 5, 10, and 20\% lactose. Biotechnol Lett 1986;8:593-6.

Brady D, Marchant R, McHale L, McHale AP. Production of ethanol by the thermotolerant yeast Kluyveromyces marxianus IMB3 during growth on lactose-containing media. Biotechnol Lett 1994;16:737-40.

Brady D, Marchant R, Mchale L, Mchale AP. The effects of $\mathrm{Mn}^{2+}$ on ethanol production by Kluyveromyces marxianus IMB3 during growth on lactose-containing media at $45^{\circ} \mathrm{C}$. Biotechnol Lett 1995;17:233-6. 
Brady D, Nigam P, Marchant R, Singh D, McHale AP. The effect of $\mathrm{Mn}^{2+}$ on ethano production from lactose using Kluyveromyces marxianus IMB3 immobilized in magnetically responsive matrices. Bioprocess Eng 1997;17:31-4.

Breunig KD, Bolotin-Fukuhara M, Bianchi MM, Bourgarel D, Falcone C, Ferrero I, et al. Regulation of primary carbon metabolism in Kluyveromyces lactis. Enzyme Microbiol Technol 2000;26:771-80.

Casey GP, Ingledew WMM. Ethanol tolerance in yeasts. CRC Crit Rev Microbiol 1986;13: 219-80.

Castrillo JI, Ugalde UO. Patterns of energy metabolism and growth kinetics of Kluyveromyces marxianus in whey chemostat culture. Appl Microbiol Biotechnol 1993;40:386-93.

Castrillo JI, Kaliterna J, Weusthuis RA, van Dijken JP, Pronk JT. High-cell-density cultivation of yeasts on disaccharides in oxygen-limited batch cultures. Biotechnol Bioeng 1996;49:621-8.

Cheryan M, Mehaia MA. A high-performance membrane bioreactor for continuous fermentation of lactose to ethanol. Biotechnol Lett 1983;5:519-24.

Compagno C, Tura A, Ranzi BM, Martegani E. Bioconversion of lactose whey to fructose diphosphate with recombinant Saccharomyces cerevisiae cells. Biotechnol Bioeng 1993;42:398-400.

Compagno C, Porro D, Smeraldi C, Ranzi BM. Fermentation of whey and starch by transformed Saccharomyces cerevisiae cells. Appl Microbiol Biotechnol 1995;43:822-5.

Cot M, Loret MO, Francois J, Benbadis L. Physiological behaviour of Saccharomyces cerevisiae in aerated fed-batch fermentation for high level production of bioethanol. FEMS Yeast Res 2007;7:22-32.

Dale MC, Eagger A, Okos MR. Osmotic inhibition of free and immobilized Kluyveromyces marxianus anaerobic growth and ethanol productivity in whey permeate concentrate. Process Biochem 1994;29:535-44.

Detroy RW, Julian G. Biomass conversion: fermentation chemicals and fuels. Crit Rev Microbiol 1982;10:203-28.

Domingues L, Dantas MM, Lima N, Teixeira JA. Continuous ethanol fermentation of lactose by a recombinant flocculating Saccharomyces cerevisiae strain. Biotechnol Bioeng 1999a;64:692-7.

Domingues L, Teixeira JA, Lima N. Construction of a flocculent Saccharomyces cerevisiae fermenting lactose. Appl Microbiol Biotechnol 1999b;51:621-6.

Domingues L, Onnela ML, Teixeira JA, Lima N, Penttila M. Construction of a flocculent brewer's yeast strain secreting Aspergillus niger $\beta$-galactosidase. Appl Microbio Biotechnol 2000a;54:97-103.

Domingues L, Vicente AA, Lima N, Teixeira JA. Applications of yeast flocculation in biotechnological processes. Biotechnol Bioprocess Eng 2000b;5:288-305.

Domingues L, Lima N, Teixeira JA. Alcohol production from cheese whey permeate using genetically modified flocculent yeast cells. Biotechnol Bioeng 2001:72:507-14.

Domingues L, Teixeira JA, Penttila M, Lima N. Construction of a flocculent Saccharomyces cerevisiae strain secreting high levels of Aspergillus niger $\beta$-galactosidase. App Microbiol Biotechnol 2002;58:645-50.

Domingues L, Oliveira C, Castro I, Lima N, Teixeira JA. Production of $\beta$-galactosidase from recombinant Saccharomyces cerevisiae grown on lactose. J Chem Technol Biotechnol 2004;79:809-15.

Domingues L, Lima N, Teixeira JA. Aspergillus niger $\beta$-galactosidase production by yeast in a continuous high cell density reactor. Process Biochem 2005;40:1151-4.

Doyle A. Another step in biofuel supply. Irish Farmers Journal Interactive. 2005 (available online <http://www.farmersjournal.ie/2005/1008/farmmanagement/crops/index. shtml> last visited: 1st June 2009).

Dragone G, Mussatto SI, Oliveira JM, Teixeira JA. Characterisation of volatile compounds in an alcoholic beverage produced by whey fermentation. Food Chem 2009;112: 929-35.

Farahnak F, Seki T, Ryu DD, Ogrydziak D. Construction of lactose-assimilating and high ethanol producing yeasts by protoplast fusion. Appl Environ Microbiol 1986;51: $362-7$

Ferrari MD, Loperena L, Varela H. Ethanol production from concentrated whey permeate using a fed-batch culture of Kluyveromyces fragilis. Biotechnol Lett 1994;16:205-10.

Fonseca GG, Heinzle E, Wittmann C, Gombert AK. The yeast Kluyveromyces marxianus and its biotechnological potential. Appl Microbiol Biotechnol 2008:79:339-54.

Fukuhara H. Kluyveromyces lactis-a retrospective. FEMS Yeast Res 2006;6:323-4.

Gancedo JM. Yeast carbon catabolite repression. Microbiol Mol Biol Rev 1998;62: $334-61$.

Gänzle MG, Haase G, Jelen P. Lactose: crystallization, hydrolysis and value-added derivatives. Int Dairy J 2008;18:685-94

Gawel J, Kosikowski FV. Improving alcohol fermentation in concentrated ultrafiltration permeates of cottage cheese whey. J Food Sci 1978:43:1717-9.

Ghaly AE, El-Taweel AA. Effect of micro-aeration on the growth of Candida pseudotropicalis and production of ethanol during batch fermentation of cheese whey. Bioresour Techno 1995a;52:203-17.

Ghaly AE, El-Taweel AA. Effect of nutrient supplements addition on ethanol production from cheese whey using Candida pseudotropicalis under batch condition. Appl Biochem Biotechnol 1995b;53:107-31.

Ghaly AE, El-Taweel AA. Continuous ethanol production from cheese whey fermentation by Candida pseudotropicalis. Energy Sources A Recover Util Environ 1997a;19: 1043-63.

Ghaly AE, El-Taweel AA. Kinetic modelling of continuous production of ethanol from cheese whey. Biomass Bioenergy 1997b;12:461-72.

Gianetto A, Berruti F, Glick BR, Kempton AG. The production of ethanol from lactose in a tubular reactor by immobilized cells of Kluyveromyces fragilis. Appl Microbio Biotechnol 1986:24:277-81.

Gibson A. Ethanol from whey. Sustainable Energy Conference, 26-27 July, Palmerston North, New Zealand. 2006 (available online <http://energy.massey.ac.nz/Confer ence\%202006/Ethanol\%20from\%20Whey\%20-\%20A\%20Gibson.pdf> last visited: 2nd June 2009).
Gödecke A, Zachariae W, Arvanitidis A, Breunig KD. Coregulation of the Kluyveromyces lactis lactose permease and $\beta$-galactosidase genes is achieved by interaction of multiple LAC9 binding sites in a $2.6 \mathrm{kbp}$ divergent promoter. Nucleic Acids Res 1991;19:5351-8

Goffrini P, Ferrero I, Donnini C. Respiration-dependent utilization of sugars in yeasts: a determinant role for sugar transporters. J Bacteriol 2002;184:427-32.

Grba S, Stehlik-Tomas V, Stanzer D, Vahcic N, Skrlin A. Selection of yeast strain Kluyveromyces marxianus for alcohol and biomass production on whey. Chem Biochem Eng Q 2002;16:13-6.

Grubb CF, Mawson AJ. Effects of elevated solute concentrations on the fermentation of lactose by Kluyveromyces marxianus Y-113. Biotechnol Lett 1993;15:621-6.

Guimarães PMR, Virtanen H, Londesborough J. Direct evidence that maltose transport activity is affected by the lipid composition of brewer's yeast. J Inst Brew 2006;112: 203-9.

Guimarães PMR, François J, Parrou JL, Teixeira JA, Domingues L. Adaptive evolution of a lactose-consuming Saccharomyces cerevisiae recombinant. Appl Environ Microbiol 2008a;74:1748-56.

Guimarães PMR, Le Berre V, Sokol S, François J, Teixeira JA, Domingues L. Comparative transcriptome analysis between original and evolved recombinant lactoseconsuming Saccharomyces cerevisiae strains. Biotechnol J 2008b;3:1591-7.

Guimarães PMR, Teixeira JA, Domingues L. Fermentation of high concentrations of lactose to ethanol by engineered flocculent Saccharomyces cerevisiae. Biotechnol Lett 2008c;30:1953-8.

Gunasekaran P, Kamini NR. High ethanol productivity from lactose by immobilized cells of Kluyveromyces fragilis and Zymomonas mobilis. World J Microbiol Biotechnol 1991;7:551-6.

Guo X, Zhou J, Xiao D. Improved ethanol production by mixed immobilized cells of Kluyveromyces marxianus and Saccharomyces cerevisiae from cheese whey powder solution fermentation. Appl Biochem Biotechnol 2010;160:532-8.

Hahn-Hägerdal B. Comparison between immobilized Kluyveromyces fragilis and Saccharomyces cerevisiae coimmobilized with $\beta$-galactosidase, with respect to continuous ethanol production from concentrated whey permeate. Biotechnol Bioeng 1985;27: 914-6.

Hamilton R. The manufacture of ethanol from whey. Chemical Processes in New Zealand: New Zealand Institute of Chemistry; 1998 (available online $<$ http://www. nzic.org.nz/ChemProcesses/dairy/3H.pdf> last visited: 2nd June 2009).

Holsinger VH, Posati LP, de Vilbiss ED. Whey beverages: a review. J Dairy Sci 1974;57: 849-59.

Izaguirre ME, Castillo FJ. Selection of lactose-fermenting yeast for ethanol production from whey. Biotechnol Lett 1982;4:257-62.

Janssens JH, Burris N, Woodward A, Bailey RB. Lipid-enhanced ethanol production by Kluyveromyces fragilis. Appl Environ Microbiol 1983;45:598-602.

Janssens JH, Bernard A, Bailey RB. Ethanol from whey-continuous fermentation with cell recycle. Biotechnol Bioeng 1984;26:1-5.

Jones TD, Havard JM, Daugulis AJ. Ethanol production from lactose by extractive fermentation. Biotechnol Lett 1993;15:871-6.

Juraščík M, Guimarães P, Klein J, Domingues L, Teixeira J, Markoš J. Kinetics of lactose fermentation using a recombinant Saccharomyces cerevisiae strain. Biotechnol Bioeng 2006;94:1147-54.

Kamini NR, Gunasekaran P. Simultaneous ethanol production from lactose by Kluyveromyces fragilis and Zymomonas mobilis. Curr Microbiol 1987;16:153-7.

Kamini NR, Gunasekaran P. Ethanol production from lactose by coculture of Kluyveromyces fragilis and Zymomonas mobilis. J Ferment Bioeng 1989;68:305-9.

Kargi F, Ozmihci S. Utilization of cheese whey powder (CWP) for ethanol fermentations: effects of operating parameters. Enzyme Microb Technol 2006;38:711-8.

Klein J, Maia J, Vicente AA, Domingues L, Teixeira JA, Juraščík M. Relationships between hydrodynamics and rheology of flocculating yeast suspensions in a high-celldensity airlift bioreactor. Biotechnol Bioeng 2005;89:393-9.

Kleine R, Achenbach S, Thoss S. Whey disposal by deproteinization and fermentation. Acta Biotechnol 1995;15:139-48.

Kosikowski FV. Whey utilization and whey products. J Dairy Sci 1979;62:1149-60.

Kosikowski FV, Wzorek W. Whey wine from concentrates of reconstituted acid whey powder. J Dairy Sci 1977;60:1982-6.

Kourkoutas Y, Dimitropoulou S, Kanellaki M, Marchant R, Nigam P, Banat IM, et al. Hightemperature alcoholic fermentation of whey using Kluyveromyces marxianus IMB3 yeast immobilized on delignified cellulosic material. Bioresour Technol 2002a;82: 177-81.

Kourkoutas Y, Psarianos C, Koutinas AA, Kanellaki M, Banat IM, Marchant R. Continuous whey fermentation using kefir yeast immobilized on delignified cellulosic material. J Agric Food Chem 2002b;50:2543-7.

Kumar V, Ramakrishnan S, Teeri TT, Knowles JKC, Hartley BS. Saccharomyces cerevisiae cells secreting an Aspergillus niger $\beta$-galactosidase grow on whey permeate. Biotechnology 1992;10:82-5.

Kurtzman CP, Fell JW, editors. The yeasts, a taxonomic study. Amsterdam: Elsevier; 1998. Lachance MA. Kluyveromyces van der Walt emend van der Walt. In: Kurtzman CP, Fell JW, editors. The yeasts, a taxonomic study. Amsterdam: Elsevier; 1998. p. 227-47.

Lewandowska M, Kujawski W. Ethanol production from lactose in a fermentation/ pervaporation system. J Food Eng 2007;79:430-7.

Ling KC. Whey to ethanol: a biofuel role for dairy cooperatives? Washington DC: USDA Rural Development; 2008 (available online <http://www.rurdev.usda.gov/RBS/ pub/RR214.pdf > last visited: 1st June 2009).

Linko YY, Jalanka H, Linko P. Ethanol production from whey with immobilized living yeast. Biotechnol Lett 1981;3:263-8.

Longhi LGS, Luvizetto DJ, Ferreira LS, Rech R, Ayub MAZ, Secchi AR. A growth kinetic model of Kluyveromyces marxianus cultures on cheese whey as substrate. J Ind Microbiol Biotechnol 2004;31:35-40. 
Lyons TP, Cunningham JD. Fuel alcohol from whey. Am Dairy Rev 1980;42:42A-E.

Mahmoud MM, Kosikowski FV. Alcohol and single cell protein production by Kluyveromyces in concentrated whey permeates with reduced ash. J Dairy Sci 1982;65:2082-7.

Martegani E, Brambilla L, Porro D, Ranzi BM, Alberghina L. Alteration of cell population structure due to cell lysis in Saccharomyces cerevisiae cells overexpressing the GAL4 gene. Yeast 1993;9:575-82.

Maullu C, Lampis G, Desogus A, Ingianni A, Rossolini GM, Pompei R. High-level production of heterologous protein by engineered yeasts grown in cottage cheese whey. Appl Environ Microbiol 1999;65:2745-7.

Mehaia MA, Cheryan M. Ethanol from hydrolyzed whey permeate using Saccharomyces cerevisiae in a membrane recycle bioreactor. Bioprocess Eng 1990;5:57-61.

Moulin G, Boze H, Galzy P. Inhibition of alcoholic fermentation by substrate and ethanol. Biotechnol Bioeng 1980;22:2375-81.

Moulin G, Boze H, Galzy P. A comparative study of the inhibitory effect of ethanol and substrates on the fermentation rate of parent and a respiratory-deficient mutant. Biotechnol Lett 1981;3:351-6.

Müller. Theo Müller Group: Company Portrait. Aretsried, http://www.muellergroup. com/fileadmin/website/Die_Gruppe/Unternehmensportrait_UTM_Stand_ 2009_engl.pdf, last visited: 2nd June, 2009.

Nehlin JO, Carlberg M, Ronne H. Yeast galactose permease is related to yeast and mammalian glucose transporters. Gene 1989;85:313-9.

Nonklang S, Abdel-Banat BMA, Cha-Aim K, Moonjai N, Hoshida H, Limtong S, et al. Hightemperature ethanol fermentation and transformation with linear DNA in the thermotolerant yeast Kluyveromyces marxianus DMKU3-1042. Appl Environ Microbiol 2008;74:7514-21.

Oda Y, Nakamura K. Production of ethanol from the mixture of beet molasses and cheese whey by a 2-deoxyglucose-resistant mutant of Kluyveromyces marxianus. FEMS Yeast Res 2009;9:742-8.

OECD-FAO. OECD-FAO Agricultural Outlook 2008-2017 Highlights. Paris: Organisation for Economic Co-operation and Development-Food and Agriculture Organization of the United Nations, 2008 (available online <http://www.agri-outlook.org/ dataoecd/54/15/40715381.pdf > last visited: 1st June 2009).

O'Leary VS, Green R, Sullivan BC, Holsinger VH. Alcohol production by selected yeast strains in lactase-hydrolyzed acid whey. Biotechnol Bioeng 1977;19:1019-35.

Oliveira C, Teixeira JA, Lima N, Da Silva NA, Domingues L. Development of stable flocculent Saccharomyces cerevisiae strain for continuous Aspergillus niger $\beta$-galactosidase production. J Biosci Bioeng 2007;103:318-24.

Ozmihci S, Kargi F. Comparison of yeast strains for batch ethanol fermentation of cheese-whey powder (CWP) solution. Lett Appl Microbiol 2007a;44:602-6.

Ozmihci S, Kargi F. Continuous ethanol fermentation of cheese whey powder solution: effects of hydraulic residence time. Bioprocess Biosyst Eng 2007b;30:79-86.

Ozmihci S, Kargi F. Effects of feed sugar concentration on continuous ethanol fermentation of cheese whey powder solution (CWP). Enzyme Microbiol Technol 2007c;41:876-80

Ozmihci S, Kargi F. Ethanol fermentation of cheese whey powder solution by repeated fed-batch operation. Enzyme Microbiol Technol 2007d;41:169-74.

Ozmihci S, Kargi F. Kinetics of batch ethanol fermentation of cheese-whey powder (CWP) solution as function of substrate and yeast concentrations. Bioresour Technol 2007e;98:2978-84.

Ozmihci S, Kargi F. Ethanol production from cheese whey powder solution in a packed column bioreactor at different hydraulic residence times. Biochem Eng J 2008;42: $180-5$.

Pesta G, Meyer-Pittroff R, Russ W. Utilization of whey. In: Oreopoulou V, Russ W, editors. Utilization of by-products and treatment of waste in the food industry. Springer; 2007.

Porro D, Martegani E, Ranzi BM, Alberghina L. Development of high cell density cultures of engineered Saccharomyces cerevisiae cells able to grow on lactose. Biotechnol Lett 1992a; $14: 1085-8$.

Porro D, Martegani E, Ranzi BM, Alberghina L. Lactose/whey utilization and ethanol production by transformed Saccharomyces cerevisiae cells. Biotechnol Bioeng 1992b;39:799-805.

Ramakrishnan S, Hartley BS. Fermentation of lactose by yeast cells secreting recombinant fungal lactase. Appl Environ Microbiol 1993;59:4230-5.

RFA. Renewable Fuels Association: Statistics. Washington DC, http://www.ethanolrfa. org/industry/statistics/, last visited: 2nd April, 2009.

Ribeiro O, Gombert AK, Teixeira JA, Domingues L. Application of the Cre-loxP system for multiple gene disruption in the yeast Kluyveromyces marxianus. J Biotechnol 2007;131: 20-6.

Rogosa M, Browne HH, Whittier EO. Ethyl alcohol from whey. J Dairy Sci 1947;30: 263-9.

Rosenberg M, Tomaska M, Kanuch J, Sturdik E. Improved ethanol production from whey with Saccharomyces cerevisiae using permeabilized cells of Kluyveromyces marxianus. Acta Biotechnol 1995;15:387-90.

Roukas T, Lazarides HN. Ethanol production from deproteinized whey by $\beta$-galactosidase coimmobilized cells of Saccharomyces cerevisiae. J Ind Microbiol 1991;7:15-8.

Rubio-Texeira M. A comparative analysis of the GAL genetic switch between not-sodistant cousins: Saccharomyces cerevisiae versus Kluyveromyces lactis. FEMS Yeast Res 2005;5:1115-28.

Rubio-Texeira M. Endless versatility in the biotechnological applications of Kluyveromyces LAC genes. Biotechnol Adv 2006;24:212-25.

Rubio-Texeira M, Castrillo JI, Adam AC, Ugalde UO, Polaina J. Highly efficient assimilation of lactose by a metabolically engineered strain of Saccharomyces cerevisiae. Yeast 1998;14:827-37.
Ryu YW, Jang HW, Lee HS. Enhancement of ethanol tolerance of lactose assimilating yeast strain by protoplast fusion. J Microbiol Biotechnol 1991;1:151-6.

Schaffrath R, Breunig KD. Genetics and molecular physiology of the yeast Kluyveromyces lactis. Fungal Genet Biol 2000;30:173-90.

Shabtai Y, Mandel C. Control of ethanol production and monitoring of membrane performance by mass-spectrometric gas analysis in the coupled fermentationpervaporation of whey permeate. Appl Microbiol Biotechnol 1993;40:470-6.

Silveira WB, Passos F, Mantovani HC, Passos FML. Ethanol production from cheese whey permeate by Kluyveromyces marxianus UFV-3: a flux analysis of oxido-reductive metabolism as a function of lactose concentration and oxygen levels. Enzyme Microbiol Technol 2005;36:930-6.

Siso MIG. The biotechnological utilization of cheese whey: a review. BioresTechnol 1996;57:1-11

Siso MIG, Ramil E, Cerdan ME, Freire Picos MA. Respirofermentative metabolism in Kluyveromyces lactis: ethanol production and the Crabtree effect. Enzyme Microbiol Technol 1996;18:585-91.

Smithers GW. Whey and whey proteins-from 'gutter-to-gold'. Int Dairy J 2008;18: 695-704.

Snoek IS, Steensma HY. Why does Kluyveromyces lactis not grow under anaerobic conditions? Comparison of essential anaerobic genes of Saccharomyces cerevisiae with the Kluyveromyces lactis genome. FEMS Yeast Res 2006;6:393-403.

Snoek IS, Steensma HY. Factors involved in anaerobic growth of Saccharomyces cerevisiae Yeast 2007;24:1-10.

Sreekrishna K, Dickson RC. Construction of strains of Saccharomyces cerevisiae that grow on lactose. Proc Natl Acad Sci U S A 1985;82:7909-13.

Staniszewski M, Kujawski W, Lewandowska M. Semi-continuous ethanol production in bioreactor from whey with co-immobilized enzyme and yeast cells followed by pervaporative recovery of product-Kinetic model predictions considering glucose repression. J Food Eng 2009;91:240-9.

Szczodrak J, Szewczuk D, Rogalski J, Fiedurek J. Selection of yeast strain and fermentation conditions for high-yield ethanol production from lactose and concentrated whey. Acta Biotechnol 1997;17:51-61.

Tahoun MK, El-Nemr TM, Shata OH. Ethanol from lactose in salted cheese whey by recombinant Saccharomyces cerevisiae. Z Lebensm.-Unters-Forsch A Eur Food Res Technol 1999;208:60-4.

Tahoun MK, El-Nemr TM, Shata $\mathrm{OH}$. A recombinant Saccharomyces cerevisiae strain for efficient conversion of lactose in salted and unsalted cheese whey into ethanol. Nahrung 2002;46:321-6.

Taya M, Honda H, Kobayashi T. Lactose-utilizing hybrid strain derived from Saccharomyces cerevisiae and Kluyveromyces lactis by protoplast fusion. Agric Biol Chem 1984;48: 2239-43.

Teixeira JA, Mota M, Goma G. Continuous ethanol production by a flocculating strain of Khyveromyces marxianus: bioreactor performance. Bioprocess Eng 1990:5:123-7.

Terrell SL, Bernard A, Bailey RB. Ethanol from whey: continuous fermentation with a catabolite repression-resistant Saccharomyces cerevisiae mutant. Appl Environ Microbiol 1984;48:577-80.

Thiele JH. Estimate of the energy potential for fuel ethanol from putrescible waste in New Zealand. Dunedin: Waste Solutions Ltd; 2005 (available online <http://www. bioenergy.org.nz/documents/liquidbiofuels/energy-potential-for-fuel-ethanolfrom-putrescible-waste-in-nz-report-05.pdf> last visited: 2nd June 2009).

van Ooyen AJ, Dekker P, Huang M, Olsthoorn MM, Jacobs DI, Colussi PA, et al. Heterologous protein production in the yeast Kluyveromyces lactis. FEMS Yeast Res 2006;6:381-92.

Vienne P, von Stockar U. An investigation of ethanol inhibition and other limitations occurring during the fermentation of concentrated whey permeate by Kluyveromyces fragilis. Biotechnol Lett 1985;7:521-6.

Wang CJ, Bajpai RK. A mathematical model of ethanol fermentation from cheese whey 1. Model development and parameter estimation. Appl Biochem Biotechnol 1997a;63-5: 495-509.

Wang CJ, Bajpai RK. A mathematical model of ethanol fermentation from cheese whey 2. Simulation and comparison with experimental data. Appl Biochem Biotechnol 1997b;63-5:511-25.

Webb BH, Whittier EO. The utilization of whey: a review. J Dairy Sci 1948;31:139-64

Whittier EO. Lactose and its utilization: a review. J Dairy Sci 1944;7:505-37.

Yalçin AS. Emerging therapeutic potential of whey proteins and peptides. Curr Pharm Des 2006;12:1637-43.

Yang ST, Silva EM. Novel products and new technologies for use of a familiar carbohydrate milk lactose. J Dairy Sci 1995;78:2541-62.

You KM, Rosenfield CL, Knipple DC. Ethanol tolerance in the yeast Saccharomyces cerevisiae is dependent on cellular oleic acid content. Appl Environ Microbiol 2003;69:1499-503.

Zadow JG. Lactose-properties and uses. J Dairy Sci 1984;67:2654-79.

Zafar S, Owais M. Ethanol production from crude whey by Kluyveromyces marxianus. Biochem Eng J 2006;27:295-8.

Zafar S, Owais M, Salleemuddin M, Husain S. Batch kinetics and modelling of ethanolic fermentation of whey. Int J Food Sci Technol 2005;40:597-604.

Zall RR. Trends in whey fractionation and utilization, a global perspective. J Dairy Sci 1984;67:2621-9.

Zertuche L, Zall RR. Optimizing alcohol production from whey using computer technology. Biotechnol Bioeng 1985;27:547-54.

Zhao XQ, Bai FW. Yeast flocculation: new story in fuel ethanol production. Biotechnol Adv 2009;27:849-56. 